\title{
A double-negative $\left(\operatorname{IgD}^{-} \mathrm{CD}_{27}^{-}\right) \mathrm{B}$ cell population is increased in the peripheral blood of elderly people
}

\author{
Giuseppina Colonna-Romano ${ }^{\mathrm{a}, *}$, Matteo Bulati ${ }^{\mathrm{a}}$, Alessandra Aquino ${ }^{\mathrm{a}}$, Mariavaleria Pellicanò ${ }^{\mathrm{a}}$, \\ Salvatore Vitello ${ }^{\mathrm{b}}$, Domenico Lio $^{\mathrm{a}}$, Giuseppina Candore ${ }^{\mathrm{a}}$, Calogero Caruso ${ }^{\mathrm{a}}$ \\ ${ }^{a}$ Gruppo di Studio sull'Immunosenescenza, Dipartimento di Biopatologia e Metodologie Biomediche, Università di Palermo, Corso Tukory 211, 90134 Palermo, Italy \\ ${ }^{\mathrm{b}}$ AUSL6 Dipartimento Cure Primarie Servizio Dipartimentale Anziani e A.D.I., Palermo, Italy
}

\section{A R T I C L E I N F O}

\section{Article history:}

Received 21 March 2008

Received in revised form 20 July 2009

Accepted 7 August 2009

Available online 19 August 2009

\section{Keywords:}

B lymphocyte

Immunosenescence

IgD

CD27

Elderly

Immunologic memory

\begin{abstract}
S U M M A R Y
The $T$ cell branch of the immune system has been extensively studied in the elderly and it is known that the elderly have impaired immune function, mainly due to the chronic antigenic load that ultimately causes shrinkage of the $\mathrm{T}$ cell repertoire and filling of the immunologic space with memory $\mathrm{T}$ cells. In the present paper, we describe the $\mathrm{IgD}^{-} \mathrm{CD}_{2} 7^{-}$double-negative $\mathrm{B}$ cell population which (as we have recently described) is higher in the elderly. Most of these cells were $\operatorname{IgG}^{+}$. Evaluation of the telomere length and expression of the $\mathrm{ABCB} 1$ transporter and anti-apoptotic molecule, $\mathrm{Bcl} 2$, shows that they have the markers of memory B cells. We also show that these cells do not act as antigen presenting cells, as indicated by the low levels of CD80 and DR, nor do they express significant levels of the CD40 molecule necessary to interact with T lymphocytes through the ligand, CD154. Hence, we hypothesize that these expanded cells are late memory or exhausted cells that have down-modulated the expression of CD27 and filled the immunologic space in the elderly. These cells might be the age-related manifestation of time-enduring stimulation or dysregulation of the immune system.
\end{abstract}

(c) 2009 Elsevier Ireland Ltd. All rights reserved.

\section{Introduction}

The immune system of the elderly has been extensively studied, for the most part involving the T cell branch (Miller, 2000; Pawelec et al., 2002a). As a result, we know that the elderly have decreased immune function due mainly to the chronic antigenic load that ultimately causes shrinkage of the $T$ cell repertoire and filling of the immunologic space with memory T cells (Franceschi et al., 2000; Pawelec et al., 2005). The direct consequence of these changes, together with the reduced output of naïve cells from the thymus (Pawelec et al., 2002a), is a reduction of antigen-inexperienced $\mathrm{T}$ lymphocytes available for adequate immune response against newly encountered antigens, in particular, infectious agents (Pawelec et al., 2002b, 2004, 2005).

In contrast to T cells, B lymphocytes have not been extensively studied in the elderly (Weksler, 2000; Weksler and Szabo, 2000; Colonna-Romano et al., 2003), although the B cell branch is involved in some hematological cancers common in the elderly, such as chronic lymphatic leukemia (Chiorazzi et al., 2005), and in the increased autoimmune responses observed in the elderly (Candore et al., 1997). On the other hand, although B cells are

\footnotetext{
* Corresponding author. Tel.: +39 0916555906; fax: +39 0916555933.

E-mail address: gcolonna@unipa.it (G. Colonna-Romano).
}

numerically reduced in the elderly (Globerson and Effros, 2000; Colonna-Romano et al., 2002), total serum immunoglobulin levels do not actually change (Le Maoult et al., 1997; Weksler and Szabo, 2000). However, we have recently reported a reduced ability of the elderly to produce IgD that is expressed together with IgM on mature B cells newly produced by the bone marrow, as demonstrated by low serum levels of this isotype (Listì et al., 2006). Interestingly, we have also shown an age-related increase in $\operatorname{IgG}$ and IgA levels, whereas there is an age-related decrease in IgM levels (Listì et al., 2006). We and others (Colonna-Romano et al., 2003; Gupta et al., 2005) have also shown that in the elderly there is a significant decrease in naïve $C D 27^{-}$B lymphocytes and no significant reciprocal increase in $\mathrm{CD} 27^{+}$memory B cells (Klein et al., 1998; Agematsu et al., 2000). On the other hand, Shi et al. (2005) have shown that $\mathrm{CD}_{2} 7^{+}$memory $\mathrm{B}$ cells, particularly $\operatorname{IgD}^{+} \operatorname{IgM}^{+} \mathrm{CD} 27^{+} \operatorname{IgM}$ memory $\mathrm{B}$ cells, decline dramatically in elderly subjects.

Different subsets of memory $\mathrm{CD}_{2} 7^{+} \mathrm{B}$ cells and $\mathrm{CD} 27^{-}$naïve B cells have been described (Shi et al., 2003; Fecteau et al., 2006; Wei et al., 2007), providing the immunity and ageing fields with new opportunities to gain insight into B cell immunosenescence. Accordingly, we have recently focused our attention on B cell subpopulations, demonstrating that a double-negative (DN) $\operatorname{IgD}^{-} \mathrm{CD}_{27}{ }^{-} \mathrm{B}$ cell subset is significantly higher in the elderly (Colonna-Romano et al., 2008). In the present report, we describe 
the characteristics of this subset of B cells present in both young and old donors. We suggest that these cells, which are expanded in the elderly, might be the age-related manifestation of a timeenduring stimulation or dysregulation of the immune system.

\section{Materials and methods}

\subsection{Subjects}

Eighty-eight healthy Sicilian subjects were studied (thirty-nine young, age range 20-55 years, mean $37.5 \pm 17.5$, median 35 years) and forty-nine elderly (age range $75-102$ years, mean $89.0 \pm 13$, median 91 years). None of the selected subjects had neoplastic, infectious, autoimmune diseases, or received any medications influencing immune function at the time of the study. All subjects gave informed consent according to Italian law.

\subsection{Cell preparation, activation, B lymphocyte separation, and flow cytometry analysis}

Peripheral blood mononuclear cells (PBMCs) were isolated from heparinized venous blood by density gradient centrifugation on Ficoll-Lympholyte (Cedarlane Laboratories Limited, Ontario, Canada). PBMCs were adjusted to $1 \times 10^{6} / \mathrm{ml}$ in RPMI 1640 medium (Euroclone, Devon, UK) supplemented with $10 \%$ heat-inactivated fetal calf serum (Euroclone), $1 \%$ penicillin/streptomicin, $10 \mathrm{mM}$ HEPES, and $1 \mathrm{mM} \mathrm{L}$ glutamine.

In some experiments PBMCs have been activated with unmethylated singlestranded DNA motif (CpG oligonucleotides), or with anti-BCR [F( $\left.\left.\mathrm{ab}^{\prime}\right)_{2}\right]$ (Jackson ImmunoResearch Laboratories, Inc, Philadelphia) as follows: PBMCs were isolated from heparinized venous blood by density gradient centrifugation on FicollLympholyte (Cedarlane Laboratories Limited, Ontario, Canada), then were adjusted to $1 \times 106 / \mathrm{ml}$ in RPMI 1640 medium (Euroclone, Devon, UK) supplemented with $10 \%$ heat-inactivated fetal calf serum (Euroclone), 1\% penicillin/streptomicin, $10 \mathrm{mM}$ HEPES, and $1 \mathrm{mM}$ L-glutamine. Cells were then cultured in 24-well plate bottom in medium or were activated with $10 \mu \mathrm{g} / \mathrm{ml}$ of $\mathrm{CpG}$ oligodeoxynucleotide (TIB Molbiol, Genova, Italy), or with $2 \mu \mathrm{g} / \mathrm{ml}$ of $\left.\mathrm{F}\left(\mathrm{ab}^{\prime}\right)_{2}\right)$, for 5 days. Then Ki67 expression was evaluated (see below).

B lymphocytes were separated from PBMCs by immunomagnetic sorting, as described by Miltenyi et al. (1990) using anti-CD19 magnetic microbeads (MACS CD19 Multisort Microbeads; Miltenyi Biotec, Aubum, CA, USA). The cells obtained from immunomagnetic sorting were $>98 \%$ CD $19^{+}$lymphocytes, as determined by flow cytometry analysis.

Total PBMCs or purified B cells were stained with different combinations of the following monoclonal antibodies: anti-IgD $\mathrm{FITC}_{\text {, anti-IgG }}$ FTC, anti-CD40 $\mathrm{PE}$, anti-HLA$\mathrm{DR}_{\mathrm{PE}}$, anti-CD19 $9_{\mathrm{PE}}$, anti-IgD $\mathrm{PE}_{\mathrm{PE}}$, and anti-CD27 $7_{\mathrm{APC}}$ (Pharmingen, BD Bioscience, Mountain View, CA, USA), anti-CD80 ${ }_{\mathrm{TC}}^{\mathrm{TM}}$ (Caltag, Burlingame, CA, USA).

For Ki67 evaluation (Lopez et al., 1991), activated PBMCs were first stained with anti-IgD $D_{\mathrm{PE}}$ or anti IgG $\mathrm{PE}_{\mathrm{P}}$ anti-CD19 ${ }_{\mathrm{PEC} 55}$, anti-CD27 $7_{\mathrm{APC}}$. Then the cells were fixed with $100 \mu \mathrm{l}$ of Perm \& Fix Solution A (Caltag Burlingame) for 20 min at $4{ }^{\circ} \mathrm{C}$, washed twice with PBS-BSA (0.2\%) and permeabilized with $500 \mu$ l of Perm \& Fix Solution B (Caltag Burlingame) for $10 \mathrm{~min}$ at RT. Then cells were stained for $40 \mathrm{~min}$ on ice with $20 \mu \mathrm{l}$ of anti-Ki67FITC (Pharmingen). After two washings the Ki67 positive cells were analyzed.

All measurements were made with a FACSCalibur flow cytometer (Becton Dickinson, San Jose, CA, USA) with the same instrument setting. At least $10^{4}$ cells were analyzed using CellQuestPro (Becton Dickinson, San Jose, CA, USA) software.

\subsection{Bromodeoxyuridine (BrdU) incorporation}

To evaluate bromodeoxyuridine (BrdU) incorporation, separated PBMCs were cultured in 24-well plate bottom in medium with $10 \mu \mathrm{M}$ of BrdU (kit BDBioscience) and then they were activated with $10 \mu \mathrm{g} / \mathrm{ml}$ of $\mathrm{CpG}$ oligodeoxynucleotide (TIB Molbiol, Genova, Italy) or $2 \mu \mathrm{g} / \mathrm{ml}$ of $\mathrm{F}\left(\mathrm{ab}^{\prime}\right)_{2}$ (Jackson Immunoresearch) for 5 days. Activated PBMC were first stained with anti-CD27FITC, anti-IgDPE, antiCD19PECy5. Then the cells were fixed with $100 \mu$ l of Perm \& Fix Solution A (Caltag Burlingame) for $20 \mathrm{~min}$ at $4{ }^{\circ} \mathrm{C}$, washed twice with PBS-BSA (0.2\%) and permeabilized with $500 \mu \mathrm{l}$ of Perm \& Fix Solution B (Caltag Burlingame) for $20 \mathrm{~min}$ at RT, washed twice and incubated with $300 \mu \mathrm{g} / \mathrm{ml}$ of DNase (kit BDBioscience) for $60 \mathrm{~min}$ at $37^{\circ} \mathrm{C}$. Then cells were re-suspended in $50 \mu \mathrm{l}$ of PBS and stained with $1 \mu \mathrm{l}$ of anti-BrdU $\mathrm{APC}_{\mathrm{A}}$ (kit BD-Bioscience) for 20 min at RT, washed and analyzed.

\subsection{Evaluation of the ATP-binding cassette-B1 transporter (ABCB1)}

To evaluate the $\mathrm{ABCB} 1$ transporter, $\mathrm{CD} 19^{+}$cells were incubated with $25 \mu \mathrm{M}$ of cyclosporin $\mathrm{A}$, which allows the exposure of the epitope of the active conformation of the ABCB1 protein (Wirths and Lanzavecchia, 2005), and $20 \mu$ of anti-ABCB1 $1_{\mathrm{PE}}$ (clone UIC2 MsIgG2a; Coulter Immunotech, Marseille Cedex, France), for $1 \mathrm{~h}$ at $37^{\circ} \mathrm{C}$ in a water bath. Then the cells were incubated for $20 \mathrm{~min}$ at room temperature with anti-CD27 $7_{\mathrm{APC}}$ and anti-IgD $\mathrm{FITC}_{\mathrm{F}}$. The fluorescence was then measured with a FACSCalibur flow cytometer. The results are expressed as the mean fluorescence intensity (MFI) mean \pm SE.

\subsection{Evaluation of telomere length}

Telomere length was evaluated by the flow-fish technique, as described by Rufer et al. (1998). Magnetically sorted $\mathrm{CD}_{19^{+}} \mathrm{B}$ cells were labelled with antibodies specific for the surface markers (i.e. anti-IgD FITC $_{\text {and }}$ anti-CD27 $7_{\mathrm{APC}}$ ) and washed with phosphate buffered saline (PBS) with $0.2 \%$ weight/volume of bovine serum albumin (BSA; Sigma Chemical Co, St. Louis, MO, USA Then the cells were fixed and permeabilizated with Fix and Perm (Caltag, Burlingame, CA, USA), according to the manufacturer's instructions. Briefly, cells were first incubated with $100 \mu \mathrm{l}$ of solution A for $15 \mathrm{~min}$ in the dark at room temperature, washed with PBS $0.2 \%$ BSA, then incubated for $15 \mathrm{~min}$ with solution $\mathrm{B}$ under the same conditions, and washed twice with PBS-BSA (0.2\%). PBMCs were then washed twice with hybridization solution containing 70\% de-ionized formamide, $20 \mathrm{mM}$ Tris (pH 7.1), 1\% BSA, and $15 \mathrm{mM} \mathrm{NaCl}$ (Sigma Chemical). The cell pellet was gently re-suspended with $200 \mu \mathrm{l}$ of hybridization solution and incubated with $0.3 \mathrm{mg} / \mathrm{ml}$ of $\left(\mathrm{C}_{3} \mathrm{TA}_{2}\right)_{3}$ PNA probe Cy5conjugated (Applied Biosystems, Bedford, MA, USA). The cell suspension was maintained at room temperature for $10 \mathrm{~min}$ prior to denaturation in a circulating water bath at $87^{\circ} \mathrm{C}$ for $15 \mathrm{~min}$. Hybridization was performed for $90 \mathrm{~min}$ at room temperature in the dark. Four washes were performed at room temperature by adding $1 \mathrm{ml}$ of $70 \%$ de-ionized formamide, $10 \mathrm{mM}$ Tris ( $\mathrm{pH} \mathrm{7.1),0.1 \%} \mathrm{BSA}$, and $0.1 \%$ Tween 20 (Sigma Chemical), followed by centrifugation of the tubes at $1500 \times g$ for $5 \mathrm{~min}$ at $16^{\circ} \mathrm{C}$ and aspiration of the supernatant, leaving $100 \mu \mathrm{l}$ in which the cell pellet was gently re-suspended before addition and mixing with $1 \mathrm{ml}$ of fresh wash fluid. The last wash step was performed with $1 \mathrm{ml}$ of $5 \%$ glucose, containing $10 \mathrm{mM}$ Hepes, $0.1 \%$ BSA, and $0.1 \%$ Tween 20 (Sigma Chemical), and centrifugation was at $900 \mathrm{~g}$ for $5 \mathrm{~min}$ at $16^{\circ} \mathrm{C}$. The cell pellet was shaken and the cells were counterstained with FACSFlow (Becton Dickinson) containing 0.1\% BSA.

The fluorescence was then measured with a FACSCalibur flow cytometer. The results are expressed as the MFI mean \pm SE of the PNA probe incorporation.

\subsection{Intracellular staining of $\mathrm{Bcl} 2$}

CD19 ${ }^{+}$lymphocytes were firstly stained with anti-IgD FITC $_{\text {and }}$ anti-CD27 $7_{\text {APC }}$. Then the cells were permeabilizated with $150 \mu$ l of permeabilization buffer (Pharmingen, BD Bioscience, Mountain View, CA, USA) for $20 \mathrm{~min}$ at room temperature, washed twice with PBS-BSA $(0.2 \%)$ and stained for $30 \mathrm{~min}$ at room temperature with $20 \mu \mathrm{l}$ of anti-Bcl2 $\mathrm{PE}$ (Pharmingen). After two washings, the Bcl2-positive cells were analyzed. The results are expressed as the MFI mean $\pm \mathrm{SE}$.

\subsection{Statistical analysis}

Values (percentage or MFI), given as the mean \pm SD or SE, were compared using one-way analysis of variance (ANOVA). Differences were considered significant when a $p$ value $<0.05$ was obtained by comparison between the different groups.

\section{Results}

\subsection{Analyses of $C D 19^{+}$cell subpopulations on the basis of $\operatorname{Ig} D$ and CD27 expression}

We analyzed circulating CD19+ lymphocytes obtained from the peripheral blood of young and elderly subjects. The analyses were performed after staining B cells identified by anti-CD19 antibody or sorted by immunomagnetic beads with a combination of antiIgD and anti-CD27 fluorochrome-conjugated antibodies. In both cases, the results were similar (data not shown). As shown in Fig. 1, we identified $\operatorname{IgD}^{+} \mathrm{CD} 27^{-}, \operatorname{IgD}^{+} \mathrm{CD} 27^{+}, \operatorname{IgD}^{-} \mathrm{CD} 27^{+}$, and $\operatorname{IgD}^{-} \mathrm{CD} 27^{-}$ (i.e. DN) B cells. Remarkably, in the elderly we observed a significant reduction of $\operatorname{IgD}^{+} \mathrm{CD} 27^{-}$naïve B cells (young, $49.5 \pm 2.9$; elderly, $40.1 \pm 3.9 ; p=0.005)$ and a highly significant increase of $\mathrm{IgD}^{-} \mathrm{CD}^{-} 7^{-}$(DN) B cells (young, $5.8 \pm 0.5$; elderly, $14.9 \pm 2.1$; $p=0.0001$ ). No differences in the percentage of the other two subpopulations of B cells were found.

\subsection{Immunoglobulin expression of DN B cells}

We evaluated the expression of membrane immunoglobulin on DN B cells. Initial presumptive evidence suggested to us that these cells were IgG-positive. In fact, the percentages of DN cells and $\operatorname{IgG}^{+} \mathrm{CD} 27^{-}$were nearly the same in the subjects studied (data not shown). Further analysis of $\operatorname{IgD}^{-} \mathrm{CD} 27^{-}$DN B cells with 4-color immunofluorescence demonstrated this association (Fig. 2). Most, but not all, of these cells were IgG-positive. All the $\operatorname{IgG}^{+}$cells were $\mathrm{IgD}^{-}$, although not all the $\operatorname{IgD}^{-}$cells were $\mathrm{IgG}^{+}$, suggesting that they 

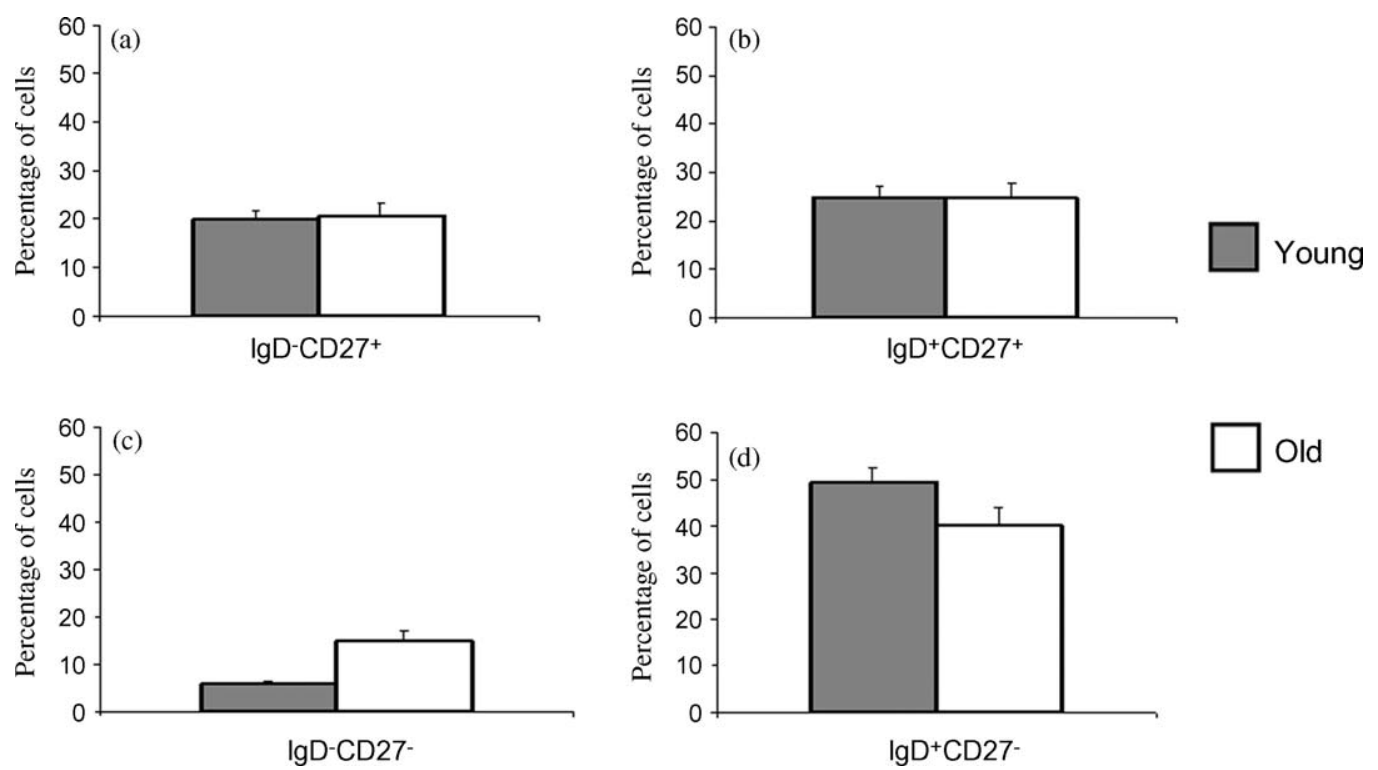

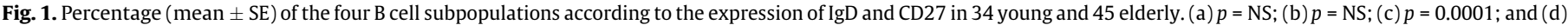
$p=0.005$.

switched the heavy chain of the immunoglobulin molecule, probably in exchange for IgA.

\subsection{ATP-binding-cassette-B1 transporter ( $A B C B 1)$ expression in $D N$ $\left(\operatorname{Ig} D^{-} \mathrm{CD} 27^{-}\right) \mathrm{B}$ cells}

We evaluated the ABCB1 levels in the four $B$ cell populations identified on the basis of IgD and CD27 expression. ABCB1 is a member of the transmembrane protein family responsible for the transport of various molecules across cell membranes (Efferth, 2003). These proteins are also extensively studied because they mediate anti-drug resistance in cancer and are thought to be involved in cytokine secretion (Efferth, 2003). As shown in box (a) of Fig. 3, as previously demonstrated by Wirths and Lanzavecchia (2005), CD $27^{+}$and CD27 ${ }^{-}$B cells express different levels of ABCB1. However, Fig. 3 shows that although it lacks CD27, the DN population of $B$ cells is $A B C B 1$-negative, as is the case in classical memory $\operatorname{IgD}^{-} \mathrm{CD}_{2} 7^{+} \mathrm{B}$ cells. On the other hand, naïve $\mathrm{B}$ cells $\left(\operatorname{IgD}^{+} \mathrm{CD} 27^{-}\right)$and unswitched memory B cells $\left(\operatorname{IgD}^{+} \mathrm{CD} 27^{+}\right)$are ABCB1-positive (Fig. 3 shows a representative experiment).

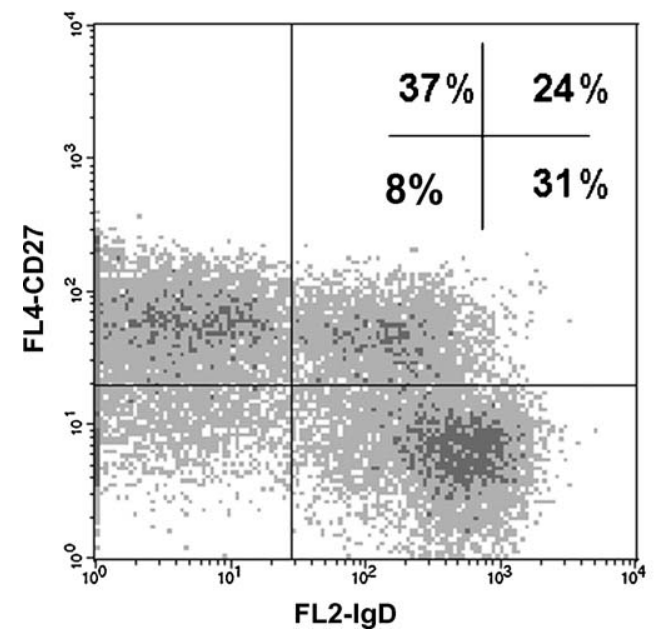

Table 1 shows the mean fluorescence intensity (MFI) values obtained in a group of young and elderly donors (12 young and 8 elderly donors). Concerning the differences between cells obtained from young or elderly subjects, we only observed a significant reduction in $A B C B 1$ expression in unswitched $B$ cells from elderly donors. Incidentally, the reduced presence of $A B C B 1$ in unswitched memory B cells of elderly donors, compared to the same population of young controls, suggests a different age-related ability in the secretion of cytokines and other molecules (Efferth, 2003) from this subpopulation. However, the amount of ABCB1 was significantly reduced in DN cells from both young and elderly donors compared to naïve and unswitched cells.

\subsection{Telomere length evaluation}

To estimate the replicative senescence of $\mathrm{DN}\left(\operatorname{IgD}^{-} \mathrm{CD} 27^{-}\right) \mathrm{B}$ cells, we evaluated the telomere length in these cells. As shown in a representative experiment in Fig. 4, naïve $B$ cells have long telomeres, whereas classic switched memory B cells $\left(\operatorname{IgD}^{-} \mathrm{CD} 27^{+}\right)$ and DN B cells have short telomeres, so they are able to go toward

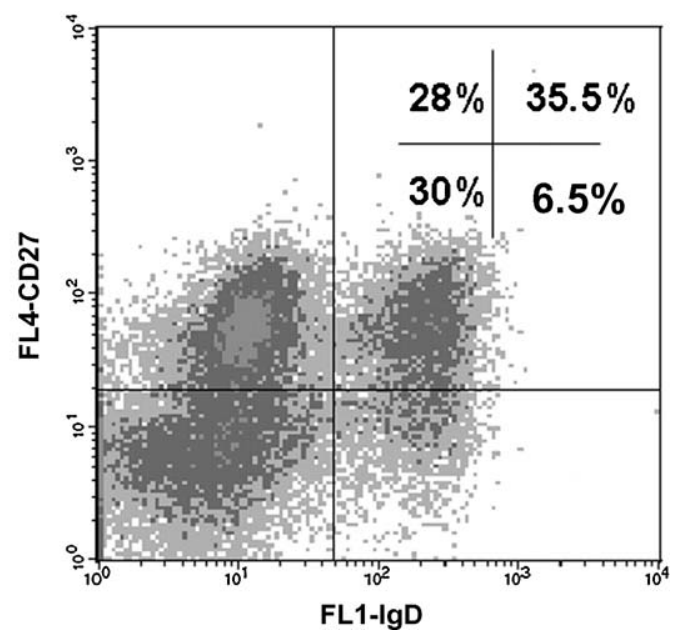

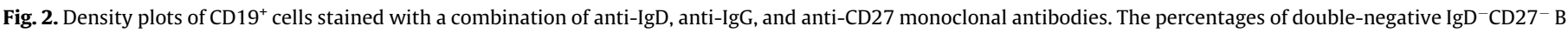
cells and of $\operatorname{IgG}^{+} \mathrm{CD} 27^{-}$B lymphocytes are marked in bold. 

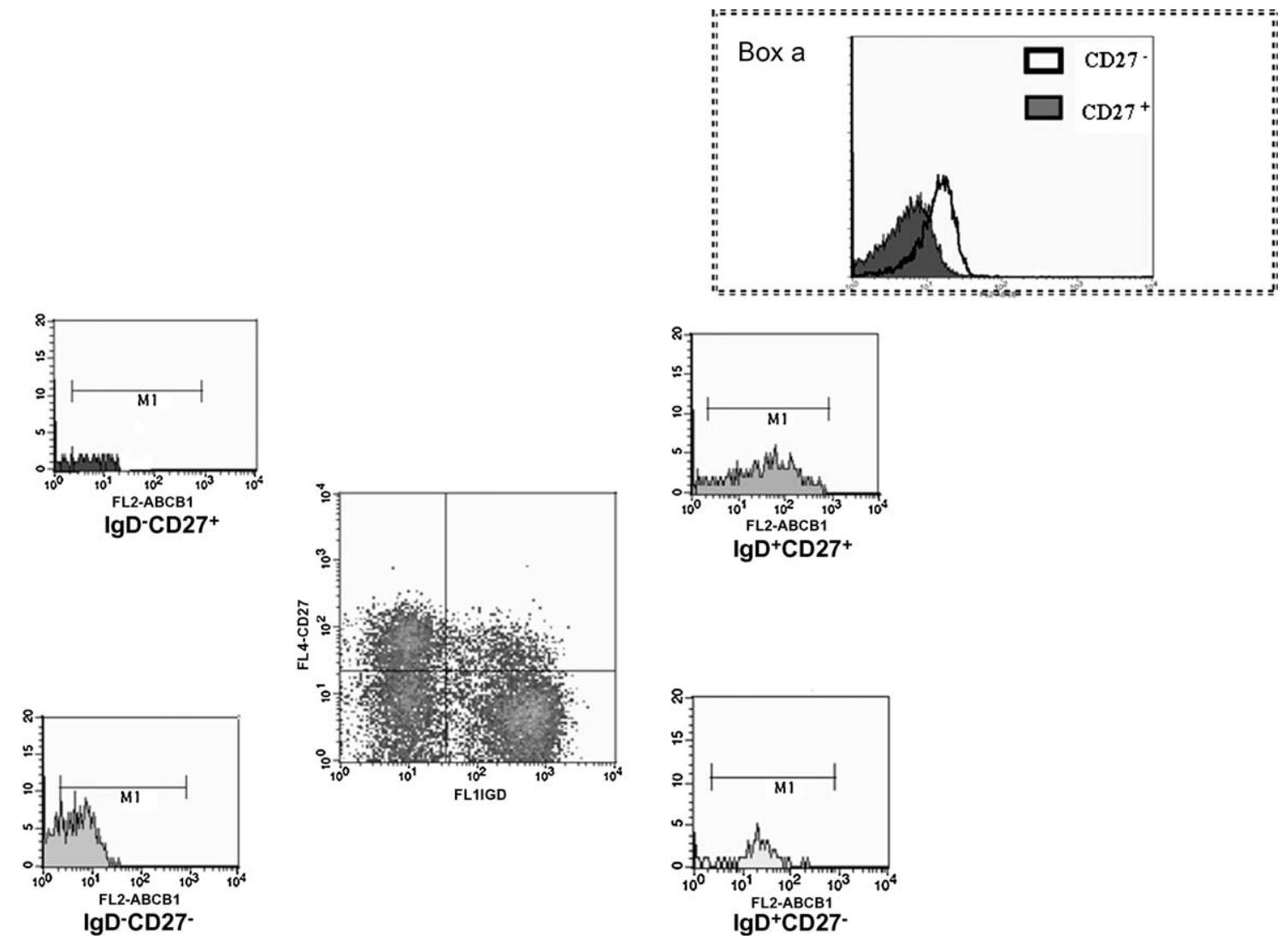

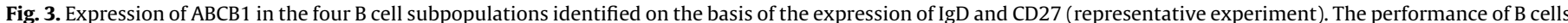

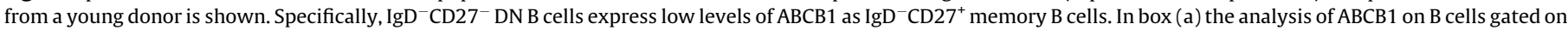

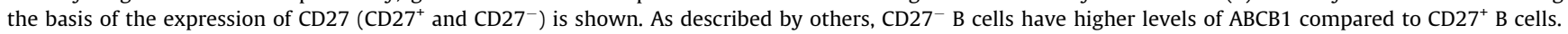

Table 1

$\mathrm{ABCB} 1$ expression (as mean $\mathrm{MFI} \pm \mathrm{SE}$ ) on the four B cell subpopulations studied in young and elderly subjects.

\begin{tabular}{|c|c|c|c|c|}
\hline & Naïve $\left(\operatorname{IgD}^{+} \mathrm{CD} 27^{-}\right)$ & Unswitched $\left(\operatorname{IgD}^{+} \mathrm{CD} 27^{+}\right)$ & Switched $\left(\operatorname{IgD}^{-} \mathrm{CD} 27^{+}\right)$ & $\mathrm{DN}\left(\mathrm{IgD}^{-} \mathrm{CD}^{2} 7^{-}\right)$ \\
\hline Young $(n=12)$ & $5.2 \pm 1.8$ & $4.9 \pm 1.3$ & $2.7 \pm 0.9$ & $2.7 \pm 0.4$ \\
\hline Elderly $(n=8)$ & $4.9 \pm 1.4$ & $2.8 \pm 1.2$ & $1.9 \pm 0.4$ & $2.4 \pm 0.8$ \\
\hline$p^{*}$ & NS & 0.015 & NS & NS \\
\hline$p^{\S}$ & 0.0009 & $<0.0001$ & NS & \\
\hline$p^{\#}$ & 0.01 & NS & NS & \\
\hline
\end{tabular}

ANOVA test: "young vs. elderly analysis; ${ }^{\S} \mathrm{DN}$ vs. the other three subpopulations in young donors; ${ }^{\#}$ DN vs. the other three subpopulations in elderly donors.

cycles of replication differently (Allsopp et al., 1992). Furthermore, Table 2 shows the MFI values indicative of telomere length in the studied subjects (12 young and 8 elderly donors). Both in the young and the elderly, memory DN cells have shorter telomeres compared to memory unswitched and naïve cells. Thus, no differences were shown between naïve and unswitched memory $B$ cells, whereas classic memory B cells and $\operatorname{IgD}^{-} \mathrm{CD}^{2} 7^{-}(\mathrm{DN}) \mathrm{B}$ cells had a very similar telomere length. $\operatorname{IgD}^{-} \mathrm{CD} 27^{+}$(switched memory) and DN B cells of elderly donors had very short telomeres compared to the same subpopulations of young donors.

\subsection{Bcl2 expression}

Individual $\mathrm{Bcl} 2$ family members couple the regulation of apoptosis and cell cycle control in unique ways. In particular, the anti-proliferative molecule, Bcl2, is anti-apoptotic (Zinkel et al., 2006). As described by Shi et al. (2003), CD27 ${ }^{+}$B lymphocytes show higher levels of $\mathrm{Bcl} 2$ compared to $\mathrm{CD} 27^{-} \mathrm{B}$ cells, and the findings in Fig. 5a confirm this. However, when we split the $\mathrm{CD} 27^{-}$population into naïve $\mathrm{IgD}^{+} \mathrm{CD} 27^{-}$and $\mathrm{DN} \mathrm{IgD}^{-} \mathrm{CD} 27^{-}$cells, we observed that DN cells had very low levels of $\mathrm{Bcl} 2$ compared to naïve $\mathrm{B}$ cells

Table 2

Telomere length evaluated by flow FISH assay. Values are expressed as the MFI (mean \pm SE) using a Cy5-conjugated PNA probe on B cell subpopulations.

\begin{tabular}{|c|c|c|c|c|}
\hline & Naïve $\left(\operatorname{IgD}{ }^{+} \mathrm{CD} 27^{-}\right)$ & Unswitched $\left(\operatorname{IgD}^{+} \mathrm{CD} 27^{+}\right)$ & Switched $\left(\operatorname{IgD}^{-} \mathrm{CD} 27^{+}\right)$ & $\mathrm{DN}\left(\mathrm{IgD}^{-} \mathrm{CD}^{2} 7^{-}\right)$ \\
\hline Young ( $n=12)$ & $170.8 \pm 17.6$ & $117.0 \pm 10.0$ & $51.4 \pm 10.0$ & $65.3 \pm 14.0$ \\
\hline Elderly $(n=8)$ & $222.8 \pm 37.6$ & $150.0 \pm 14.0$ & $21.3 \pm 2.0$ & $28.2 \pm 4.8$ \\
\hline$p^{*}$ & NS & NS & 0.01 & 0.02 \\
\hline$p^{\S}$ & 0.001 & 0.01 & NS & \\
\hline$p^{\#}$ & $<0.0005$ & 0.001 & NS & \\
\hline
\end{tabular}

ANOVA test: "young vs. elderly analysis; ${ }^{\S} \mathrm{DN}$ vs. the other three subpopulations in young donors; ${ }^{\#} \mathrm{DN}$ vs. the other three subpopulations in elderly donors. 


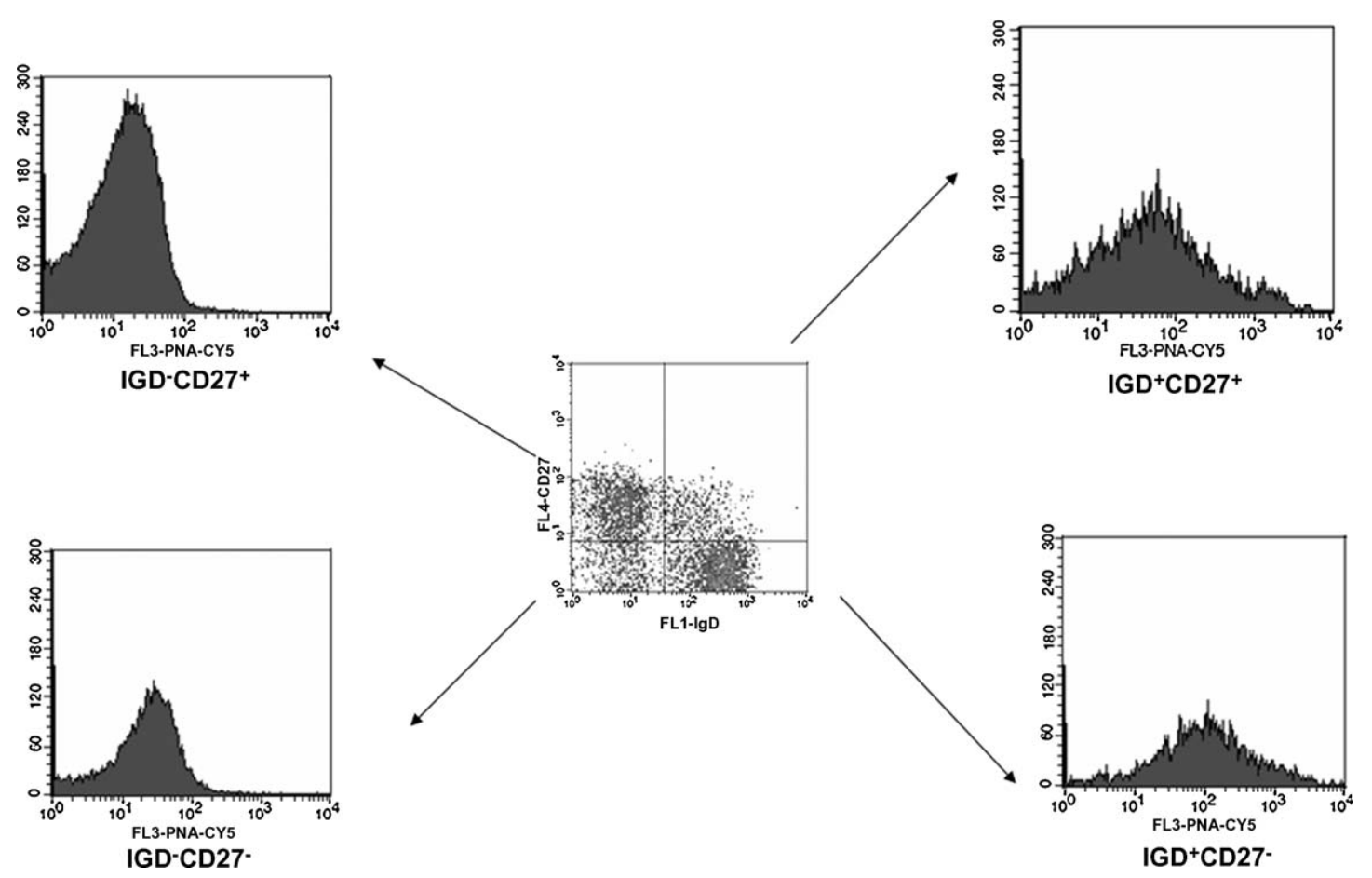

Fig. 4. Telomere length measurement by flow fish in B lymphocyte subsets according to the expression of IgD and CD27 (representative experiment). The performance of B cells obtained from a young donor is shown.
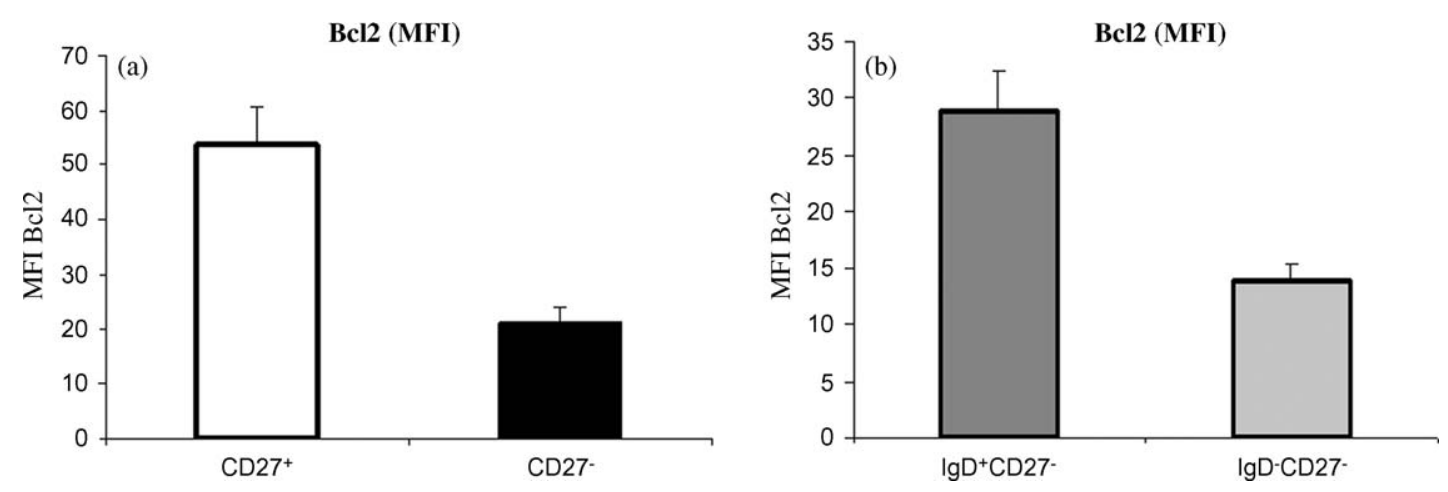

Fig. 5. (a) Bcl2 expression (mean of MFI values $\pm \mathrm{SE}$ ) on $\mathrm{CD}_{2} 7^{+}$and $\mathrm{CD} 27^{-}$B lymphocytes $\left(p<0.0001\right.$ ). (b) This last group of cells was split into IgD ${ }^{+} \mathrm{CD} 27^{-}\left(\right.$naïve) and IgD ${ }^{-} \mathrm{CD} 27^{-}$ (DN) B cells and Bcl2 expression was significantly lower $(p<0.0022 ; n=14.6$ young and 8 elderly).

(Fig. 5b). The data obtained in young and old donors were analyzed as a single group, as no differences have been revealed between the two age groups.

\subsection{CD40, HLA-DR, and CD80 expression in DN B cells}

It is well known that B cells act as good antigen presenting cells (APC; Rodriguez-Pinto, 2005) and change the heavy chain of secreted immunoglobulins after the interaction with $\mathrm{T}$ cells through CD40-CD154 ligation (Rodriguez-Pinto and Moreno, 2005). We evaluated the four B cell populations studied for the expression of HLA-DR and CD80 necessary to efficiently present antigen and the CD40 necessary to activate isotype switching (Rodriguez-Pinto, 2005; Rodriguez-Pinto and Moreno, 2005). In Table 3, we show that there was a significant reduction in CD80, HLA-DR, and CD40 expression in $\mathrm{CD} 27^{-} \mathrm{B}$ cells compared to $\mathrm{CD} 27^{+}$ cells. In Fig. 6, we show that when $\mathrm{CD}_{2} 7^{-} \mathrm{B}$ cells were split into $\operatorname{IgD}^{+} \mathrm{CD} 27^{-}$and $\mathrm{IgD}^{-} \mathrm{CD} 27^{-}$cells, $\mathrm{CD} 80$ was expressed at negligible levels in DN B cells, whereas naïve B cells showed low, but significantly higher levels of CD80 when compared to the DN population. A similar insignificant trend was observed in HLA-DR and CD40 expression. Since no differences have been revealed between the two age groups (data not shown), the data obtained in young and old donors were analyzed as a single group.

\subsection{Ki67 expression}

B lymphocytes express Toll Like receptor 9 (TLR9) that bind microbial DNA containing CpG motifs, and activation of human and murine B cells by CpG is well documented (Bekeredjian-Ding et al.,

Table 3

CD80, HLA-DR, and CD40 expression (as the MFI mean \pm SE) on $\mathrm{CD}_{27}{ }^{+}$and $\mathrm{CD} 27^{-} \mathrm{B}$ lymphocytes ( $n=14 ; 6$ young and 8 elderly).

\begin{tabular}{lllc}
\hline & CD80 & HLA-DR & CD40 \\
\hline $\mathrm{CD} 7^{+}$ & $33.0 \pm 7.9$ & $104.9 \pm 17.0$ & $104.7 \pm 14.2$ \\
$\mathrm{CD}^{-} 7^{-}$ & $11.8 \pm 2.1$ & $24.7 \pm 6.5$ & $37.9 \pm 8.2$ \\
$p$ & 0.013 & $<0.0001$ & 0.002 \\
\hline
\end{tabular}

ANOVA test: $\mathrm{CD}^{2} 7^{+}$vs. $\mathrm{CD}^{-} 7^{-}$. 
CD80 on CD27 B Iymphocytes (MFI)

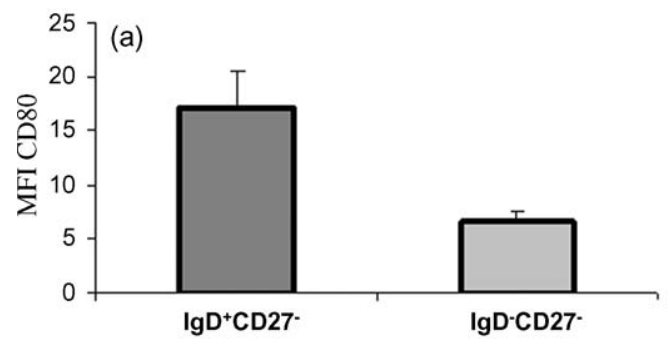

HLA-DR on CD27-B lymphocytes (MFI)

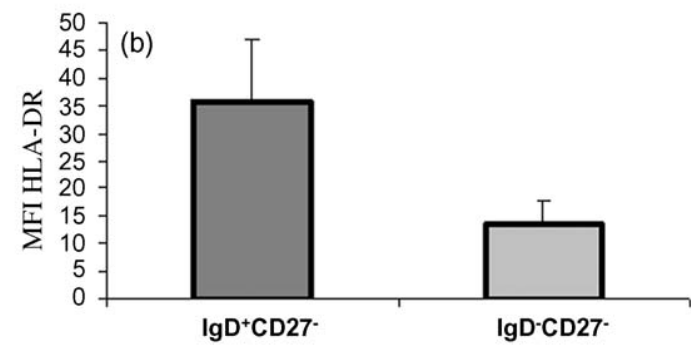

CD40 on CD27 B lymphocytes (MFI)

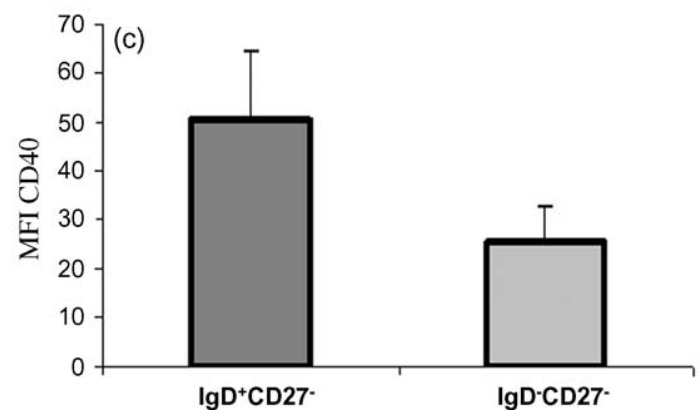

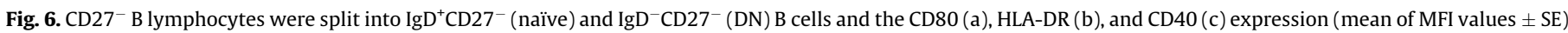
evaluated. CD80 ( $p=0.006)$, HLA-DR $(p=\mathrm{NS}), \mathrm{CD} 40(p=\mathrm{NS} ; n=14.6$ young and 8 elderly.

Table 4

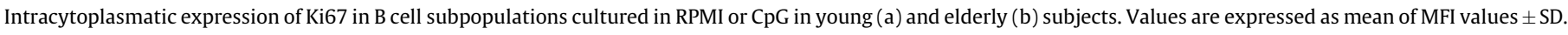

\begin{tabular}{|c|c|c|c|c|c|}
\hline \multicolumn{6}{|l|}{ (a) } \\
\hline & \multicolumn{5}{|l|}{ Young $(n=5)$} \\
\hline & Total B cells & Naïve $\left(\operatorname{IgD}^{+} \mathrm{CD} 27^{-}\right)$ & Unswitched $\left(\operatorname{IgD}^{+} \mathrm{CD} 27^{+}\right)$ & Switched $\left(\operatorname{IgD}^{-} \mathrm{CD} 27^{+}\right)$ & $\mathrm{DN}\left(\mathrm{IgD}^{-} \mathrm{CD} 27^{-}\right)$ \\
\hline RPMI & $14.0 \pm 7.4$ & $36.0 \pm 12.5$ & $74.0 \pm 56.2$ & $18.6 \pm 11.9$ & $18.4 \pm 11.8$ \\
\hline $\mathrm{CpG}$ & $118.4 \pm 64.1$ & $210.0 \pm 82.5$ & $251.5 \pm 181.7$ & $20.3 \pm 10.8$ & $25.1 \pm 18.4$ \\
\hline$p$ & $0.02^{\mathrm{a}}$ & $0.03^{\mathrm{a}}$ & $0.05^{\mathrm{a}}$ & 0.2 & 0.2 \\
\hline \multicolumn{6}{|l|}{ (b) } \\
\hline & \multicolumn{5}{|l|}{ Elderly $(n=4)$} \\
\hline & Total B cells & Naïve $\left(\operatorname{IgD}{ }^{+} \mathrm{CD}_{27^{-}}\right)$ & Unswitched $\left(\operatorname{IgD}^{+} \mathrm{CD} 27^{+}\right)$ & Switched $\left(\operatorname{IgD}{ }^{-} \mathrm{CD} 27^{+}\right)$ & $\mathrm{DN}\left(\mathrm{IgD}^{-} \mathrm{CD}^{2} 7^{-}\right)$ \\
\hline RPMI & $25.0 \pm 2.0$ & $15.7 \pm 0.5$ & $23.8 \pm 0.9$ & $49.0 \pm 7.0$ & $46.5 \pm 7.5$ \\
\hline $\mathrm{CpG}$ & $46.8 \pm 0.6$ & $36.0 \pm 3.8$ & $46.7 \pm 2.2$ & $57.8 \pm 6.6$ & $49.3 \pm 8.7$ \\
\hline$p$ & $0.02^{\mathrm{a}}$ & $0.01^{\mathrm{a}}$ & $0.01^{\mathrm{a}}$ & 0.06 & 0.06 \\
\hline
\end{tabular}

ANOVA test.

a CPG vs. RPMI.

2005). In order to assess the ability of the different memory/naïve $B$ cell subset to be activated we evaluated the Ki67 expression following 5 days of culture with CPG in PBMCs from young and elderly donors. As shown in Table 4, total B cells from young subjects are well stimulated by CpG whereas cells from elderly donors show a reduced ratio of activation (8.45 vs. 1.87). The analysis of Ki67 expression on the four B cell subsets show a remarkable Ki67 expression in naïve and memory unswitched $B$ cells of the young donors. A significant response is also observed in the same population of elderly patients, although at a reduced ratio. Memory switched and DN cells of both young and elderly donors do not show a significant proliferation. In order to validate the result obtained in DN cells, in Fig. 7 we evaluated the Ki67 expression in gated $\operatorname{IgG}^{+} \mathrm{CD} 27^{-}$(i.e. $\mathrm{DN} \operatorname{IgD}^{-} \mathrm{CD} 27^{-}$). This population does not show any staining problem.

In some young and elderly donors, we have also evaluated the Ki67 expression after 5 days of culture with $\mathrm{F}\left(\mathrm{ab}^{\prime}\right)_{2}$, a polyclonal mitogen of B cells that binds the B cell receptor (anti-BCR). In Fig. 8 we show a typical experiment to evaluate the Ki67 expression, as MFI, after stimulation of total B cells and their subsets through their BCR. Ki67 expression was enhanced in total B cells and in all the $\mathrm{B}$ subsets.

\subsection{BrdU incorporation}

The immunofluorescent staining of incorporated BrdU with flow cytometric analysis provides a high resolution technique to determine the frequency and nature of individual cells that have synthesized DNA. In this method, BrdU is incorporated into newly synthesized DNA by cells entering and progressing through the DNA synthesis phase of the cell cycle (Gratzner and Leif, 1981). To assess the ability of the different $B$ cell subset to be activated, we have also evaluated the BrdU incorporation by the proliferating cells following 5 days of culture with $\mathrm{CpG}$ or $\mathrm{F}\left(\mathrm{ab}^{\prime}\right)_{2}$ in PBMCs from young and elderly donors. As shown in a typical experiment in Fig. 9, in $\mathrm{DN}\left(\operatorname{IgD}^{-} \mathrm{CD} 27^{-}\right)$B lymphocytes, after stimulation with 

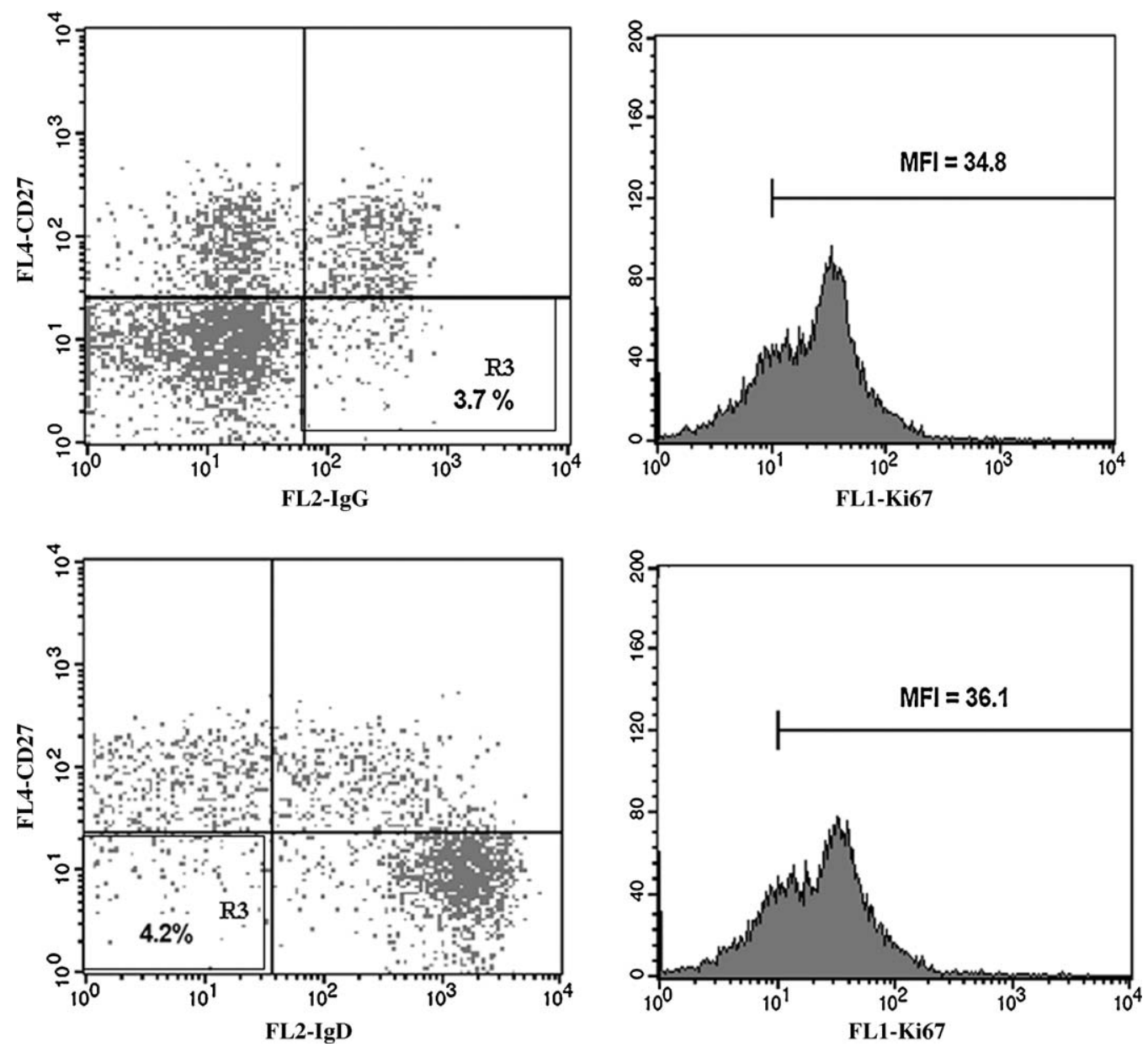

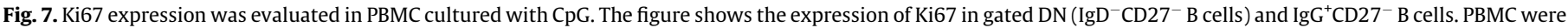
stained with anti-IgD $\mathrm{PE}_{\mathrm{P}}$ or anti IgG $_{\mathrm{PE}}$,anti-CD19 ${ }_{\mathrm{PEC} 5}$, anti-CD27 $7_{\mathrm{APC}}$ and anti-Ki67FITC.

$\mathrm{F}\left(\mathrm{ab}^{\prime}\right)_{2}$, there is a higher incorporation of the BrdU compared to the unstimulated cells or after activation with $\mathrm{CpG}$.

\section{Discussion}

Immunological memory is a characteristic feature of instructive immune responses. Immunological memory allows the immediate response by pre-induced circulating antibodies and confers the ability to mount a rapid and vigorous immune response after repeated exposure to the same antigen by memory lymphocytes (Lanzavecchia and Sallusto, 2005; Lanzavecchia et al., 2006). On the other hand, it has been demonstrated that the frequency and diversity of immune stimulation throughout life causes an increase in the number of memory $\mathrm{T}$ cells. This circumstance is repeated in long-lived subjects, rendering the elderly less able to respond to new antigens (Pawelec et al., 2002b; Pawelec et al., 2005; Akbar and Fletcher, 2005). In this regard, it has been proposed that the immunological space in elderly people is filled by memory T cells (Franceschi et al., 1995; Cossarizza et al., 1996; Franceschi et al., 2000; Globerson and Effros, 2000). Furthermore, it has been suggested that chronic antigenic stimuli, as occur with herpes viruses, play a relevant role in exhausting the immune system (Pawelec et al., 2002b; Ouyang et al., 2004; Akbar and Fletcher, 2005; Wikby et al., 2005; Colonna-Romano et al., 2007), due to the clonal expansion of CD8 T cells and the consequent shrinkage of the T cell repertoire (Pawelec et al., 2004, 2005). This state of affairs has consequences, since elderly people show an increased incidence of infections and an inadequate vaccine response (Hainz et al., 2005; Kaml et al., 2006).

As changes in the $\mathrm{B}$ cell repertoire have also been described both in mice and in humans (Weksler, 2000; Szabo et al., 2003, 2004), in this paper we have focused our attention on B memory lymphocytes in the elderly. These cells have been defined by the expression of the membrane marker, CD27, which is involved in the differentiation of B cells into antibody-secreting plasma cells (Kobata et al., 1995; Agematsu et al., 2000). CD27 ${ }^{+}$B lymphocytes have been assumed to be memory $\mathrm{B}$ cells because it has been observed that they contain somatic Ig gene mutations (Klein et al., 1998), and have switched the Ig class (Agematsu et al., 2000). Finally, it has been reported that the percentage of $\mathrm{CD} 27^{+} \mathrm{B}$ lymphocytes increase with age from cord blood to adults (Agematsu et al., 2000) and to a lesser extent, in the elderly (Colonna-Romano et al., 2003). Several years ago Shi et al. (2003) demonstrated that circulating B cells can be divided (on the basis of the expression of IgD and CD27) into three different functional subsets: (1) $\operatorname{IgD}^{+} \mathrm{CD} 27^{-}$naïve $\mathrm{B}$ cells, (2) $\operatorname{IgD}^{+} \mathrm{CD} 27^{+}$memory unswitched cells, and (3) $\operatorname{IgD}^{-} \mathrm{CD} 27^{+}$classic memory switched $\left(\operatorname{IgG}^{+}\right.$or $\left.\operatorname{Ig} \mathrm{A}^{+}\right)$cells. Some of the unswitched cells also express IgM and have been designated $\operatorname{IgM}$ memory B cells $\left(\operatorname{IgD}^{+} \operatorname{IgM}{ }^{+} C D 27^{+}\right)$, while some of the $\operatorname{IgD}^{-} \mathrm{CD} 27^{+}$(memory switched) are $\operatorname{IgM}^{+}$and have been designated IgM-only memory B cells (Shi et al., 2005). It has been proposed that IgM memory B cells are involved in the response to pneumococcal antigens and Shi et al. (2005) have demonstrated that these cells are reduced in the elderly. This 

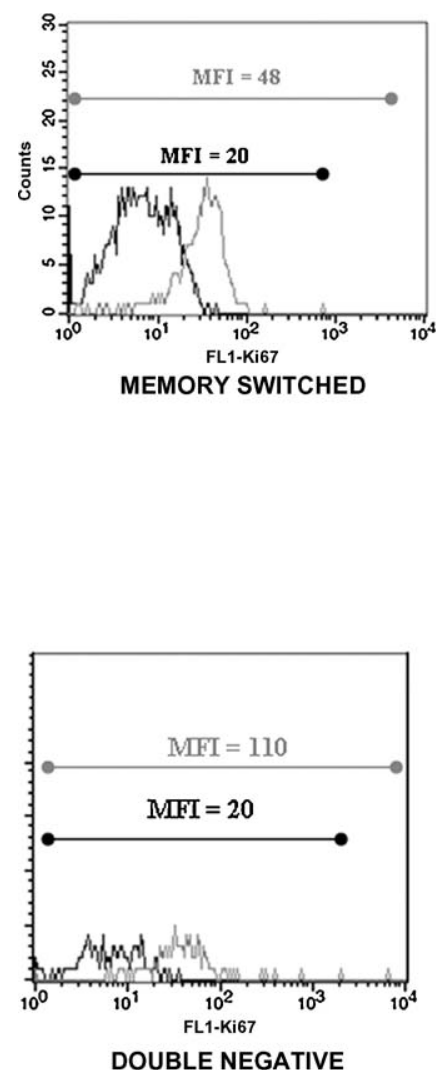

Fig. 8. Ki67 expression on B cells and their subsets after stimulation with anti-BCR $F\left(a b^{\prime}\right)_{2}$.
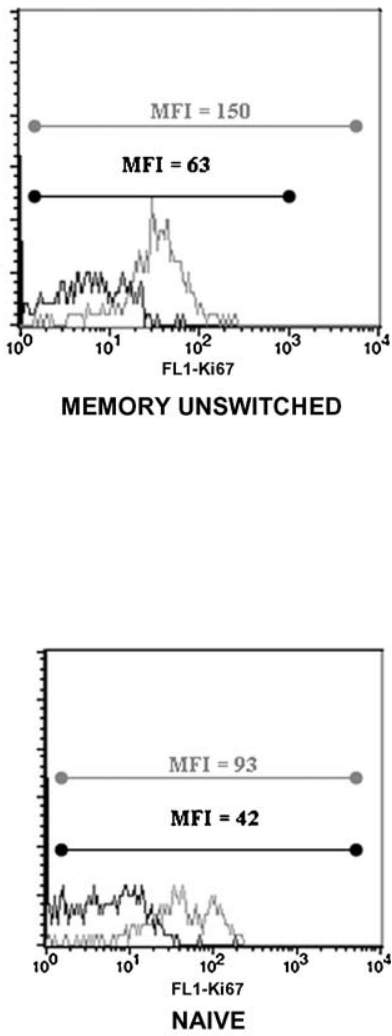

Black line: Unstimulated

Grey line: Stimulated with $\mathrm{F}(\mathbf{a b})_{2}$

MEMORY UNSWITCHED

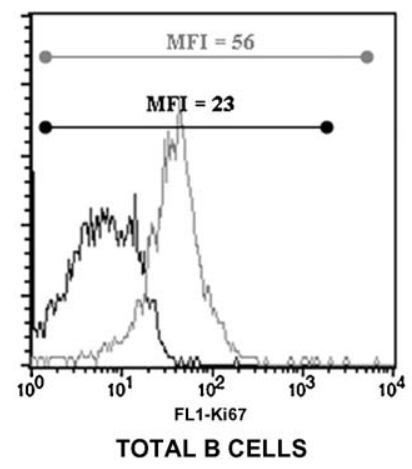

reduction is considered responsible for the increased susceptibility to bacterial infections.

Studying B cell populations in the elderly, our attention has been drawn to $B$ lymphocytes negative for both IgD and CD27. These cells are significantly higher in the elderly (Colonna-Romano et al., 2008), together with a significant reduction of naïve B cells described also by Gupta et al. (2005). The latter finding is not in agreement with the data reported by Shi (Shi et al., 2005), as they showed an increase of naïve B cells in the elderly. This was an unexpected result as it is assumed that elderly people have a highly experienced immune system and a reduced output of B cells (Globerson and Effros, 2000). In contrast, another paper (Frasca et al., 2008) reports a reduced amount (percentage and absolute number) of memory $B$ cells in the aged, and an increased percentage (but a reduced absolute number) of naïve B cells in the elderly. One possible explanation for these differences might be the age of the subject studied (our elderly subjects were mean age 89.0, median 91 years) whereas in Frasca's paper the subjects were about age 70 years. This could be a critical factor although this is not the only difference between Frasca's data and ours. The results obtained from young donors are also different. On the other hand our data obtained from young donors are consistent with data reported by Sanz et al., 2008. Moreover, the amount of IgG found in the serum by us (Listì et al., 2006), and others (Frasca et al., 2008; Franceschi et al., 1995) fits well with the expansion of $\operatorname{IgG}^{+} \mathrm{B}$ cells.

However, the important results obtained from our work are that an expanded population of DN B cells, expressing IgG but lacking $\mathrm{CD} 27\left(\mathrm{IgD}^{-} \mathrm{IgG}^{+} \mathrm{CD} 27^{-}\right)$exists in the elderly. This kind of memory B cell has also been described by Fecteau et al. (2006) in healthy donors, Wei et al. (2007) in active Lupus patients, and by Sanz et al. (2008) in healthy subjects challenged with respiratory syncizial virus (RSV). The latter author hypothesizes that these cells might participate in the early phases of protective memory responses.

To characterize DN B cells in our studied subjects, we have evaluated the expression of the ATP-binding cassette and the ABCB1 transporter, as Wirths and Lanzavecchia (2005) have demonstrated that it is exclusively present in naïve B cells and absent in memory B lymphocytes. From our data, we conclude that this very small population of B cells behaves as $\mathrm{CD} 27^{+}$memory lymphocytes because the IgD/CD27 DN population of B cells is ABCB1-negative, whereas naïve $B$ cells $\left(\mathrm{IgD}^{+} \mathrm{CD} 27^{-}\right.$) are $\mathrm{ABCB1}$ positive. Moreover unswitched memory $B$ cells from elderly donors seem to quickly acquire the memory phenotype as they lose $\mathrm{ABCB} 1$ expression.

To evaluate the age of the DN B cells, we assessed the telomere length of the four B cell populations studied. In fact, telomere length is believed to be a good marker to study cellular senescence, as well as ageing and the life expectancy of an organism (Cawthon et al., 2003). Telomere length regulates the replicative capacity of vertebrate somatic cells and reflects both the residual replicative capacity and the history of one cell (Allsopp et al., 1992).

Our results show that DN cells expanded in the elderly have a reduced replicative ability as also shown by the Ki67 expression after in vitro culture with $\mathrm{Cpg}$ but not with $\mathrm{F}\left(\mathrm{ab}^{\prime}\right) 2$. Further, we observed that DN cells have a very low level of Bcl2 when compared to naïve IgDCD27 ${ }^{+} \mathrm{CD} 27^{-} \mathrm{B}$ cells. This is an unexpected result as the presence of $\mathrm{Bcl} 2$ should preserve the cells from apoptosis and should be responsible for the survival of these cells. In fact these cells survive in vivo and in vitro (data not shown) and are able to enter in cycle as shown by a higher incorporation of BrdU in stimulated cultures compared to the unstimulated ones. Notably switched memory and DN B cells from elderly subjects in vitro show an "intrinsic" higher expression of Ki67 when cultured 


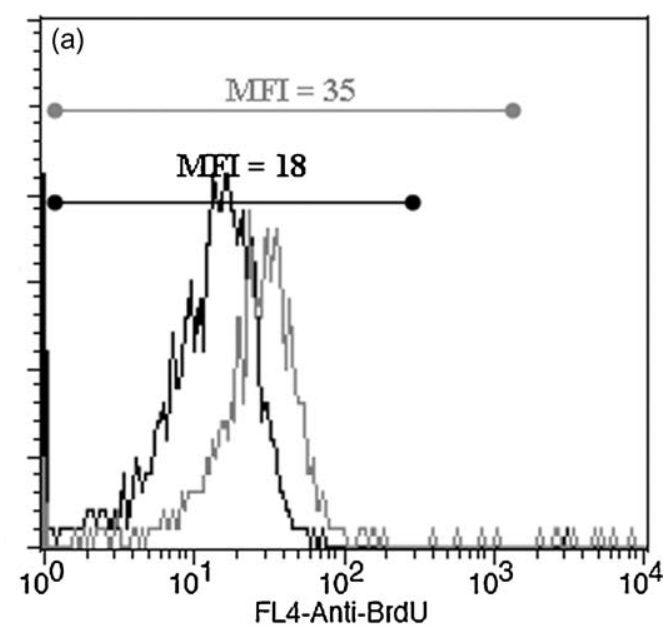

Black line: Unstimulated Grey line: Stimulated with CpG

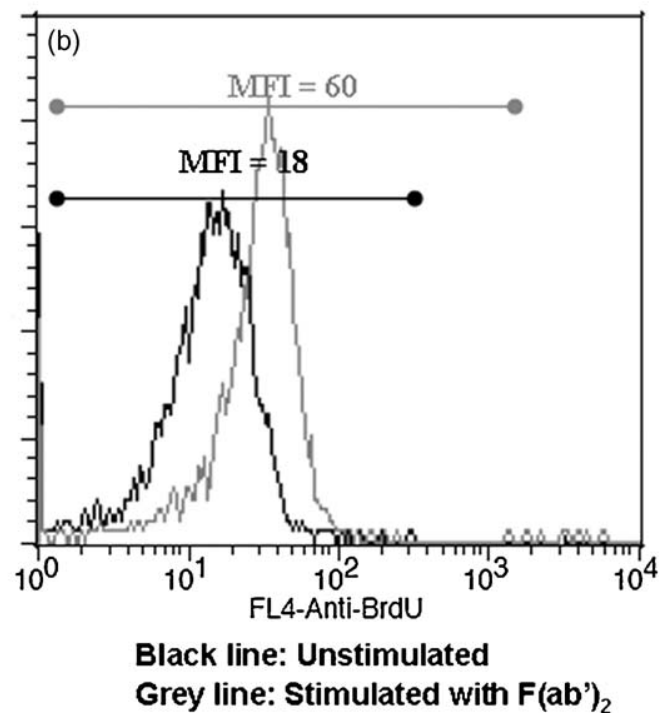

Fig. 9. BrdU incorporation on double-negative B cells after stimulation with $\mathrm{CpG}$ (a) or anti-BCR F $\left(\mathrm{ab}^{\prime}\right)_{2}$.

in medium alone. So the proliferative defect of DN B cells are limited to certain stimulators, as observed for senescent CD28-CD8 T cells (Weng et al., 2009). To gain insight into the mechanisms of this partially defective activation, further studies are needed, including cytokine production evaluation.

Regarding the role of these cells, we conclude that it is a typical phenomenon due to the ageing of the immune system; we consider these cells exhausted memory cells that have reverted their expression of CD27 as they have switched the heavy chain of immunoglobulin, have low levels of $A B C B 1$, and have short telomeres. Finally, they have low levels of $\mathrm{Bcl}-2$ and are therefore likely prone to apoptosis.

What is the biological significance of these cells? Are they exhausted and just fill the B cell immunological space, or might they have another function, such as functioning as an APC? To try to answer these questions, we evaluated the expression of HLA-DR and CD80 necessary to efficiently present antigen to $T$ cells (Rodriguez-Pinto, 2005). Moreover, as CD40-CD154 binding is necessary to activate isotype switching (Rodriguez-Pinto and Moreno, 2005), we studied the expression of CD40 on CD27 $7^{+}$and $\mathrm{CD}^{-} 7^{-} \mathrm{B}$ cells. Our negative results suggest that these cells do not express any of these markers useful for antigen presentation and T-
B cooperation. Moreover, the observation that these expanded DN $B$ cells are CD40-negative suggests that these cells might develop outside the germinal center, as this circumstance has been demonstrated in lupus-prone mice (William et al., 2002). In the elderly, immunoglobulin production might elude $\mathrm{T}$ cell control. This might explain the normal levels of Ig in the serum of old donors (Listì et al., 2006).

Our results strengthen the recent data of Wei et al. (2007) obtained in lupus patients, suggesting that these DN cells are memory B cells. The authors have debated the origin and biological meaning of DN B cells and hypothesized that these cells might be a distinct lineage of memory B cells or a progenitor of memory $\mathrm{CD} 27^{+}$cells. We instead hypothesize that these cells are senescent memory $B$ cells that have down-modulated (reverted) their expression of CD27 (Appay et al., 2002) like specific CD8 T cells against chronic antigenic stimuli (e.g. herpetic viruses; Pawelec et al., 2004, 2005). The exhaustion of the immune system in the elderly has been demonstrated in the $\mathrm{T}$ cell branch (Akbar and Fletcher, 2005), and we believe that this is also the case in the B cell compartment. On the other hand, it has been demonstrated that the time-enduring stimulation of the immune system, as in patients with lupus (Anolik et al., 2004), is related to the expansion of these cells and that the amount of DN B cells correlates positively with the clinical manifestations of lupus (Wei et al., 2007) Recent observations suggest that memory B cells are highly heterogeneous (Wirths and Lanzavecchia, 2005; Ehrhardt et al., 2005; Fecteau et al., 2006; Wei et al., 2007; Sanz et al., 2008); they might play different roles in pathologic chronic stimulation (e.g., lupus), and in chronic stimulation (e.g., the elderly). Finally, we believe that knowledge of B-cell behaviour in elderly people is a major issue in the immunesenescence field since B cells contribute to autoimmune disease, and B-cell tumors constitute the greater part of hematological cancers in the elderly (Chiorazzi et al., 2005), and B cells are also strongly related to the vaccine response.

\section{Acknowledgments}

Supported by grants of the Italian Ministry of Education, University and Research (ex60\%) to GCR and CC. MP is a PhD student at the Pathobiology PhD course (directed by C.C.) at Palermo University and this work is submitted in partial fulfilment of the requirement for the PhD degree.

\section{References}

Agematsu, K., Hokibara, S., Nagumo, H., Komiyama, A., 2000. CD27: a memory B-cell marker. Immunol. Today 21, 204-206.

Akbar, A.N., Fletcher, J.M., 2005. Memory T cell homeostasis and senescence during ageing. Curr. Opin. Immunol. 17, 480-485.

Allsopp, R.C., Vaziri, H., Patterson, C., Goldstein, S., Younglai, E.V., Futcher, A.B. Greider, C.W., Harley, C.B., 1992. Telomere length predicts peplicative capacity of human fibroblasts. Proc. Natl. Acad. Sci. U. S. A. 89, 10114-10118.

Anolik, J.A., Barnard, J., Cappione, A., Pugh-Bernard, A.E., Felgar, R.A., Looney, R.J., Sanz, I., 2004. Rituximab improves peripheral B cell abnormalities in human systemic lupus erythematosus. Arthritis Rheumat. 40, 3580-3590.

Appay, V., Dunbar, P.R., Callan, M., Klenerman, P., Gillespie, G.M.A., Papagno, L., Ogg, G.S., King, A., Lechner, F., Spina, C.A., Little, S., Havlir, D.V., Richman, D.D., Gruener, N., Pape, G., Waters, A., Easterbrook, P., Salio, M., Cerundolo, V., McMichael, A.J., Rowland-Jones, S.L., 2002. Memory $\mathrm{CD}^{+}{ }^{+} \mathrm{T}$ cells vary in differentiation phenotype in different persistent virus infections. Nat. Med. $8,379-385$.

Bekeredjian-Ding, I.B., Wagner, M., Hornung, V., Giese, T., Schnurr, M., Endres, S., Hartmann, G., 2005. Plasmacytoid dendritic cells control TLR7 sensitivity of naive B cells via type I IFN. J. Immunol. 174, 4043-4050.

Candore, G., Di Lorenzo, G., Mansueto, P., Melluso, M., Fradà, G., Li Vecchi, M., Esposito Pellitteri, M., Drago, A., Di Salvo, A., Caruso, C., 1997. Prevalence of organ-specific and non organ-specific autoantibodies in healthy centenarians. Mech. Ageing Dev. 94, 183-190.

Cawthon, R., Smith, K., O’Brien, E., Sivatchenko, A., Kerber, R.A., 2003. Association between telomere length in blood and mortality in people aged 60 years or older. Lancet 361, 393-395. 
Chiorazzi, N., Rai, K.R., Ferrarini, M., 2005. Chronic lymphocytic leukemia. N. Engl. J. Med. 352, 804-815.

Colonna-Romano, G., Cossarizza, A., Aquino, A., Scialabba, G., Bulati, M., Lio, D., Candore, G., Di Lorenzo, G., Fradà, G., Caruso, C., 2002. Age-and gender-related values of lymphocyte subsets in subjects from Northern and Southern Italy. Arch. Gerontol. Geriatr. Suppl. 8, 99-107.

Colonna-Romano, G., Bulati, M., Equino, A., Scialabba, G., Candore, G., Lio, D., Motta, M., Malaguarnera, M., Caruso, C., 2003. B cells in the aged: CD27, CD5 and CD40 expression. Mech. Ageing Dev. 124, 389-393.

Colonna-Romano, G., Akbar, A.N., Aquino, A., Bulati, M., Candore, G., Lio, D., Ammatuna, P., Fletcher, J.M., Caruso, C., Pawelec, G., 2007. Impact of CMV and EBV seropositivity on CD8 T lymphocytes in an old population from WestSicily. Exp. Gerontol. 42, 995-1002.

Colonna-Romano, G., Bulati, M., Aquino, A., Vitello, S., Lio, D., Candore, G., Caruso, C., 2008. B cell immunosenescence in elderly and centenarians. Rejuvenation Res. 11 (2), 433-439.

Cossarizza, A., Ortolani, C., Paganelli, R., Barbieri, D., Monti, D., Sansoni, P., Fagiolo, U., Castellani, G., Versani, F., Londei, M., Franceschi, C., 1996. CD45 isoforms expression on $\mathrm{CD}^{+}$and $\mathrm{CD}^{+} \mathrm{T}$ cells throughout life, from newborns to centenarians: implications for T cell memory. Mech. Aging Dev. 86, 173-195.

Efferth, T., 2003. Adenosine triphosphate-binding cassette transporter genes in ageing and age-related diseases. Ageing Res. Rev. 2, 11-24.

Ehrhardt, G.R., Hsu, J.T., Gartland, L., Leu, C.M., Zhang, S., Davis, R.S., Cooper, M.D., 2005. Expression of the immunoregulatory molecule FcRH4 defines a distinctive tissue-based population of memory B cells. J. Exp. Med. 202, 783-791.

Fecteau, J.F., Coté, G., Néron, S., 2006. A new memory CD27- $\mathrm{IgG}^{+}$B cell population in peripheral blood expressing $\mathrm{VH}$ genes with low frequency of somatic mutation. J. Immunol. 177, 3728-3736.

Franceschi, C., Bonafe, M., Valensin, S., 2000. Human immunosenescence: the prevailing of innate immunity, the failing of clonotypic immunity, and the filling of immunological space. Vaccine 18, 1717-1720.

Franceschi, C., Monti, D., Sansoni, P., Cossarizza, A., 1995. The immunology of exceptional individuals: the lesson of centenarians. Immunol. Today 16, 12-16.

Frasca, D., Landin, A.M., Lechner, S.C., Ryan, J.G., Schwartz, R., Riley, R.L., Blomberg, B.B., 2008. Aging down-regulates the transcription factor E2A, activationinduced cytidine deaminase, and Ig class switch in human B cells. J. Immunol. 180 (8), 5283-5290.

Globerson, A., Effros, R.B., 2000. Ageing of lymphocytes and lymphocytes in the aged. Immunol. Today 21, 515-521.

Gratzner, H.G., Leif, R.C., 1981. An immunofluorescence method for monitoring DNA synthesis by flow cytometry. Cytometry 1, 385-393.

Gupta, S., Su, H., Bi, R., Agrawal, S., Gollapudi, S., 2005. Life and death of lymphocytes: a role in immunesenescence. Immun. Ageing 2, 12, doi:10.1186/17424933-2-12.

Hainz, U., Jenewein, B., Asch, E., Pfeiffer, K.P., Berger, P., Grubeck-Loebenstein, B., 2005. Insufficient protection for healthy elderly adults by tetanus and TBE vaccines. Vaccine 23, 3232-3235.

Kaml, M., Weiskirchner, I., Keller, M., Luft, T., Hoster, E., Hasford, J., Young, L., Bartlett, B., Neuner, C., Fischer, K.H., Neumanf, B., Wurzner, R., Grubeck-Loebenstein, B., 2006. Booster vaccination in the elderly: their success depends on the vaccine type applied earlier in life as well as on pre-vaccination antibody titers. Vaccine 24, 6808-6811.

Klein, U., Rajewsky, K., Küppers, R., 1998. Human immunoglobulin (Ig) $\mathrm{M}^{+} \operatorname{IgD}{ }^{+}$ peripheral blood B cells expressing the CD27 cell surface antigen carry somatically mutated variable region genes: CD27 as a general marker for somatically mutated (memory) B cells. J. Exp. Med. 188, 1679-1689.

Kobata, T., Jacquot, S., Kozlowski, S., Agematsu, K., Schlossman, S.F., Morimoto, C., 1995. CD27-CD70 interactions regulate B-cell activation by T cells. Proc. Natl. Acad. Sci. U. S. A. 92, 11249-11253.

Lanzavecchia, A., Sallusto, F., 2005. Understanding the generation and function of memory T cell subsets. Curr. Opin. Immunol. 17, 326-332.

Lanzavecchia, A., Bernasconi, N., Traggiai, E., Ruprecht, C.R., Corti, D., Sallusto, F., 2006. Understanding and making use of human memory B cells. Immunol. Rev. 211, 303-309.

Le Maoult, J., Szabo, P., Weksler, M.E., 1997. Effect of age in humoral immunity, selection of the B-cell repertoire and B-cell development. Immunol. Rev. 160, 115-126.
Listì, F., Candore, G., Modica, M.A., Russo, M., Di Lorenzo, G., Esposito-Pillitteri, M., Colonna-Romano, G., Aquino, A., Bulati, M., Lio, D., Franceschi, C., Caruso, C. 2006. A study of serum immunoglobulin levels in elderly persons providing new insights into B cell immunosenescence. Ann. N. Y. Acad. Sci. 1089, 487-495.

Lopez, F., Belloc, F., Lacombe, F., Dumain, P., Reiffers, J., Bernard, P., Boisseau, M.R. 1991. Modalities of synthesis of Ki67 antigen during the stimulation of lymphocytes. Cytometry $12(1), 42-49$.

Miller, R.A., 2000. Effect of aging on T lymphocyte activation. Vaccine 18, 1654 1660.

Miltenyi, S., Muller, W., Weichel, W., Radbruch, A., 1990. A high gradient magnetic all separation with Macs. Cytometry 11, 231-238.

Ouyang, Q., Wagner, W.M., Zheng, W., Wikby, A., Remarque, E.J., Pawelec, G., 2004 Dysfunctional CMV-specific $\mathrm{CD}^{+} \mathrm{T}$ cells accumulate in the elderly. Exp. Gerontol. 39, 607-613.

Pawelec, G., Barnett, Y., Forsey, R., Frasca, D., Globerson, A., McLeod, J., Caruso, C., Franceschi, C., Fulop, T., Gupta, S., Mariani, E., Mocchegiani, E., Solana, R., 2002a. $\mathrm{T}$ cells and aging, January 2002 update. Front. Biosci. 7, d1056-d1183.

Pawelec, G., Ouyang, Q., Colonna-Romano, G., Candore, G., Lio, D., Caruso, C., 2002b. Is human immunosenescence clinically relevant? Looking for 'immunological risk phenotypes'. Trends Immunol. 23, 330-332.

Pawelec, G., Akbar, A.N., Caruso, C., Effros, R., Grubeck-Loebenstein, B., Wikby, A., 2004. Is immunosenescence infectious? Trends Immunol. 25, 406-410.

Pawelec, G., Akbar, A.N., Caruso, C., Solana, R., Grubeck-Loebenstein, B., Wikby, A 2005. Human immunosenescence: is it infectious? Immunol Rev. 20, 257-268.

Rodriguez-Pinto, D., Moreno, J., 2005. B cells can prime naive $\mathrm{CD}^{+} \mathrm{T}$ cells in vivo in the absence of other professional antigen-presenting cells in a CD154-CD40dependent manner. Eur. J. Immunol. 35, 1097-1105.

Rodriguez-Pinto, D., 2005. B cells as antigen presenting cells. Cell. Immunol. 238, 67-75.

Rufer, N., Dragowska, W., Thornbury, G., Roosnek, E., Lansdorp, P.M., 1998. Telomere length dynamics in human lymphocyte subpopulations measured by flow cytometry. Nat. Biotechnol. 16, 743-747.

Sanz, I., Wei, C., Lee, F.E., Anolik, J., 2008. Phenotypic and functional heterogeneity of human memory B cells. Semin. Immunol. 20 (1), 67-82.

Shi, Y., Agematsu, K., Ochs, H.D., Sugane, K., 2003. Functional analysis of human memory B-cell subpopulations: $\operatorname{IgD}^{+} \mathrm{CD} 27^{+} \mathrm{B}$ cells are crucial in secondary immune response by producing high affinity IgM. Clin. Immunol. 108, 128-137.

Shi, Y., Yamazaki, T., Okubo, Y., Uehara, Y., Sugane, K., Agematsu, K., 2005. Regulation of aged humoral immune defense against pneumococcal bacteria by IgM memory B cell. J. Immunol. 175, 3262-3267.

Szabo, P., Shen, S., Telford, W., Weksler, M.E., 2003. Impaired rearrangement of IgH V to DJ segments in bone marrow Pro-B cells from old mice. Cell. Immunol. 222, 78-87.

Szabo, P., Li, F., Matthew, J., Lillvis, J., Weksler, M.E., 2004. Evolution of B-cell clonal expansions with age. Cell. Immunol. 231, 158-167.

Wei, C., Anolik, J., Cappione, A., Zheng, B., Pugh-Bernard, A., Brooks, J., Lee, E.H. Milner, E.C.B., Sanz, I., 2007. A new population of cells lacking expression of CD27 represents a notable component of the B cell memory compartment in systemic lupus erythematosus. J. Immunol. 178, 6624-6633.

Weng, N.P., Akbar, A.N., Goronzy, J., 2009. CD28(-) T cells: their role in the ageassociated decline of immune function. Trends Immunol. 30, 306-312.

Weksler, M.E., Szabo, P., 2000. The effect of age on the B-cell repertoire. J. Clin. Immunol. 20, 240-249.

Weksler, M.E., 2000. Changes in the B-cell repertore with age. Vaccine 18, 1624-1628.

Wikby, A., Ferguson, F., Forsey, R., Thompson, J., Strindhall, J., Lofgren, S., Nilsson, B.O., Ernerudh, J., Pawelec, G., Johansson, B., 2005. An immune risk phenotype, cognitive impairment, and survival in very late life: impact of allostatic load in Swedish octogenarian and nonagenarian humans. J. Gerontol. A. Biol. Sci. Med. Sci. 60, 556-565.

William, J., Euler, C., Christensen, S., Shlomchik, M.J., 2002. Evolution of autoantibody responses via somatic hypermutation outside of germinal centers. Science 297, 2066-2070.

Wirths, S., Lanzavecchia, A., 2005. ABCB1 transporter discriminates human resting naïve B cells from cycling transitional and memory B cells. Eur. J. Immunol. 35 1-9.

Zinkel, S., Gross, A., Yang, E., 2006. Bcl2 family in DNA damage and cell cycle control. Cell Death Differ. 13, 1351-1359. 